\title{
Ethical Responsibilities: An Empirical Analysis Of The Ethical Codes Of The Top 100 Companies In The United Kingdom
}

Sarah D. Stanwick, (E-mail: stanwsd@auburn.edu), Auburn University Peter A. Stanwick, (E-mail: stanwpa@auburn.edu), Auburn University

\begin{abstract}
In response to ethical dilemmas faced by companies around the globe, companies are developing or refining their ethical codes. Many of these companies communicate these codes to their stakeholders through the company's corporate social responsibility (CSR) report. This paper examines the ethics' codes of the top 100 companies (based on market capitalization) in the United Kingdom. A sample of CSR reports for these companies is examined to determine if the company includes its ethical code in the CSR report, if it reports its ethical code in a separate document, or if it does not disclose the code.
\end{abstract}

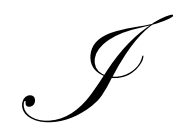

$\mathrm{n}$ response to ethical dilemmas faced by companies around the globe, companies are developing or refining their ethical codes. Many of these companies communicate these codes to their stakeholders through the company's corporate social responsibility (CSR) report. This paper examines the ethics' codes of the top 100 companies (based on market capitalization) in the United Kingdom. A sample of CSR reports for these companies is examined to determine if the company includes its ethical code in the CSR report, if it reports its ethical code in a separate document, or if it does not disclose the code. Then, the ethical code's content is examined based on criteria described in the publication by Deloitte \& Touche LLP, "Suggested Guidelines for Writing a Code of Ethics/Conduct"1. Each code is examined based on the five components of the guidelines: 1. Code Basics (e.g., apply to all employees) 2. Recommended Elements (e.g., ethical decision framework) 3. Areas of Risk 4. Potential Code Topics (e.g., customer relations) and 5. Implementation (e.g., communicate to all employees). The results of this study will be useful to academics and practitioners who are attempting to understand the development of ethical codes.

A code of ethics can be defined as any written document whose purpose is to identify to its employees behavior that is considered acceptable and unacceptable. The role of the code of ethics is to present both the positive aspects of having a strong ethical commitment (a values based approach) as well as highlight the consequences of unacceptable behavior (compliance based approach). There could three types of statements that would incorporate the description of expected behavior of the employees. Those three statements are called value statement, corporate credo and code of ethics. Why do companies need codes of ethics?

The use of corporate codes of ethics is increasing as a way to help curb the corporate scandals of this decade. In the United States, the increased use of corporate codes of ethics can be attributed to the requirements set forth in the Sarbanes-Oxley Act. However, a recent survey conducted by the Institute of Business Ethics and Fishburn Hedges suggests some interesting findings about corporate codes of ethics in the United Kingdom. The findings, based on the responses of eighty companies known to have codes of ethics, are addressed in Table 1.

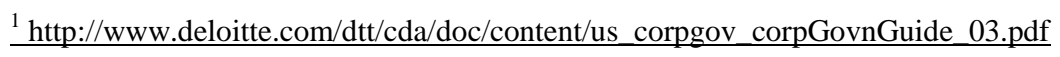




\begin{tabular}{|l|}
\hline \multicolumn{1}{|c|}{ Table $\mathbf{1}$} \\
Principal Findings of United Kingdom Company Ethics Study. Source: $\mathbf{w w w . i b e . o r g . u k}$ \\
\hline $26 \%$ of boards of directors are taking direct responsibility for the ethical programs of companies. \\
\hline $38 \%$ of the respondents say that guidance to staff is the main reason cited for having codes of ethics \\
\hline $60 \%$ of companies require conformity to their code as a clause in their contract of employment \\
\hline $41 \%$ of the respondents have used their code in disciplinary procedures in the last three years \\
\hline $58 \%$ of the respondents say they measure the effectiveness of their code by an audit or by internal review \\
\hline
\end{tabular}

As a way of communicating with stakeholders about a variety of issues, many companies, especially those headquartered in the United Kingdom, issue Corporate Social Responsibility Reports. Stakeholders would be any group that has a vested interest in the operations of a firm. Traditional stakeholders include: stockholders, suppliers, customers, the government, local communities, interest groups and society as a whole. While many corporations issue these reports in the United States, the prevalence of corporate social responsibility reports is much greater in the United Kingdom. In some cases, companies include their code of ethics in this document, while in the United States many companies will present their code of ethics as a separate document on their corporate webpage. The purpose of this paper is to examine the code of ethics presentation of companies headquartered in the United Kingdom.

\section{THE STUDY}

Based on the Global Forbes List, a sample of companies located in the United Kingdom was examined. From the population of one hundred firms on this list, a random sample of twenty firms was identified. Fourteen industries were represented. These included: utilities (2); retailing (1); food markets (1); telecommunication services (1); banking (2); aerospace and defense (2); chemicals (2); materials (2); diversified financials (1); drugs and biotechnology (1); food, drink and tobacco (2); household and personal products (1); hotels, restaurants and leisure (1); and business services and supplies (1). In aggregate, the companies included in the sample had:

- $\quad$ Average sales: $\$ 20.09$ billion

- $\quad$ Average profits: $\$ .8325$ billion

- $\quad$ Average Assets: \$135.71 billion.

Table 2 presents a list of companies included in the sample.

\begin{tabular}{|l|}
\hline \multicolumn{1}{|c|}{ Table 2 } \\
\hline Companies included in Sample \\
\hline AMDOCS \\
Anglo American \\
Associated British Foods \\
BAE Systems \\
BOC \\
Bradford and Bingley \\
Corus \\
HBOS \\
HSBC \\
Imperial Chemical Industries (ICI) \\
Ladbrokes \\
Marks and Spencer \\
National Grid Transco \\
Reckitt Benckiser \\
Rolls-Royce Group \\
Scottish and Newcastle \\
Scottish Power \\
Shire \\
Vodafone \\
William Morrison Supermarkets \\
\hline
\end{tabular}


Each of these companies' websites was explored to identify whether or not the company provided access to the corporate responsibility report. Then, the corporate social responsibility report was examined for the code of ethics. If the code of ethics was not included in the corporate social responsibility report, the website was searched to see if the company disclosed the code of ethics in another part of the webpage. This search found that $94 \%$ of the companies published a corporate social responsibility report on their corporate website. Only $6 \%$ of the companies did not publish their CSR report online. In addition, one company published its code of ethics in its corporate social responsibility report. Eleven companies published their code of ethics separately on their web pages. Eight companies did not disclose their codes of ethics on their corporate websites.

Deloitte \& Touche, one of the four largest public accounting firms, publishes guidance for companies writing a code of ethics, "Suggested Guidelines for Writing a Code of Ethics/Conduct" (www.deloitte.com). This document presents five areas for consideration when writing a code of ethics:

- $\quad$ Code Basics: presents the basic points to consider when creating or modifying a company's code? Deloitte and Touche recommend that the code language should be simple and concise and be readily understood by all of the company's employees. The code should be state expected behavior instead of legalistic "thou shall not" language. The code should be universal in its scope and its responsibilities for the employees. The code should be developed by a multidisciplinary team representing all the interests of the firm. The code should be reviewed and revised when necessary.

- $\quad$ Recommended Elements: presents a list of items to consider including in the code of ethics, for example, the mission statement and a letter from the CEO addressing the importance of ethics in the organization. In addition a listing of available resources which could be used to enable any employee to report any activities which may be considered unethical. Some of the resources which could be included are: establishing a hotline to report information, contact information for the Ethics and Compliance Officer or Office and a definition of reporting chain of command that would make a decision on the information obtained by the employee.

- $\quad$ Areas of Risk: discussion of the importance of including areas which are especially risky to the industry. For example, a heavy manufacturing company may focus more closely on environmental issues than a service company due to the higher probability that environmental ethical issues may develop.

- $\quad$ Potential Code Topics: presents a list of potential topics companies can cover in their ethics codes. Some of the potential topic areas could include: financial record keeping, bribery, antitrust issues, supplier relationships, community activities, compliance issues, conflicts of interest, corporate governance, discrimination, diversity, drugs and alcohol, environment, fraud, harassment, foreign corruption, money laundering, privacy, computer issues, security, social responsibility and workplace violence.

- Implementation: provides points to consider when developing and communicating the code to employers.

The results of the examination of the codes of ethics for these elements are summarized in Table 3.

\begin{tabular}{|c|c|c|}
\hline \multicolumn{3}{|c|}{ Table 3 } \\
Results of Codes of Ethics' Content \\
\hline Item & Number of Codes with the Item & Number of Codes without the Item \\
\hline Code Basics & 12 & 0 \\
\hline Recommended Elements & 9 & 3 \\
\hline Areas of Risk & 8 & 4 \\
\hline Potential Code Topics & 11 & 1 \\
\hline Implementation & 11 & 1 \\
\hline
\end{tabular}




\section{RESULTS}

The results have yielded some interesting findings. Of the twenty firms in the study, only twelve of the firms had their code of ethics on their web site. This was a puzzling finding for the researchers. Since one of the goals of the code of ethics was to communicate the firm's ethical benefits to its stakeholders, it is expected that all the firms in the sample would want to present their code of ethics to the general public. As a result, two alternative conclusions were developed based on this result. The first conclusion is that the other eight firms do not have a code of ethics to publish on their web site, or the firms feel that releasing their code of ethics would have some type of negative connotation of the firm.

Another interesting result was that of the firms did release their code of ethics to the public; the majority of the firms used a separate document instead of the corporate social responsibility report to disclose the information. As a result, it appears that the firms in the sample may have a slight disconnect between the role of their code of ethics and their responsibility to be good corporate social citizens.

The content analysis of the information within the code of ethics showed that the firms were relatively consistent in presenting information in the five major areas that were develop by Deloitte and Touche. All of the firms that had code of ethics addressed the basics of the code and 92 percent of the firms also addressed potential topic areas of the code and an explanation on how the code of ethics is implemented with the firm. Furthermore, 75 percent of the firms had some of the recommended elements presented by Deloitte and Touche and 67 percent had identified potential areas of ethical risk within the firm.

\section{CONCLUSIONS AND SUGGESTIONS FOR FUTURE RESEARCH}

The results of the study demonstrate that firms realize the importance of not only having a code of ethics that is available to the public, but also that it is comprehensive enough to cover multiple components based on the criteria established by Deloitte and Touche. This increased level of ethical awareness will be needed in the future for firms doing business in the United Kingdom.

In 2007, all United Kingdom companies will be required to prepare an Operating and Financial Review (OFR) based on guidelines established by the Accounting Standards Board in the United Kingdom. Many companies already publish OFRs on a voluntary basis. This Operating and Financial Review (www.ipa.co.uk/business/ofr.cfm):

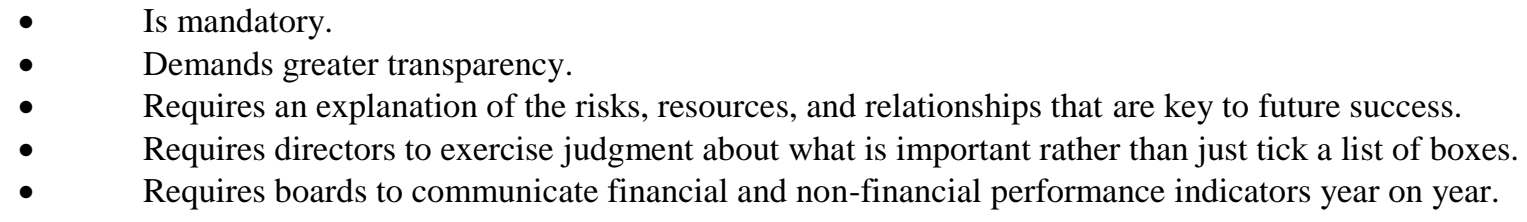

Through the OFR, companies can increase their transparency concerning corporate ethics. Ian Mackintosh, ASB Chairman, stated: "The Operating and Financial Review has for some years been an important feature of corporate reporting, providing an opportunity for directors to set out a clear and balanced analysis of the strategic position and direction of their business. Whether or not the OFR is a statutory requirement, the publication of a narrative explanation of a company's development, performance, position and prospects should continue to be encouraged as an important element of best practice. The reporting statement gives companies clear guidance and a framework within which they can achieve transparent and open communication with their shareholders." (www.frc.org.uk/asb/press/pub1029.html).

There are many areas within the OFR that companies can address corporate ethics. The checklist shown in Table 4 provides a listing of areas which should be addressed in the OFR. Discussion of corporate ethics can enhance the information disclosed by companies. 


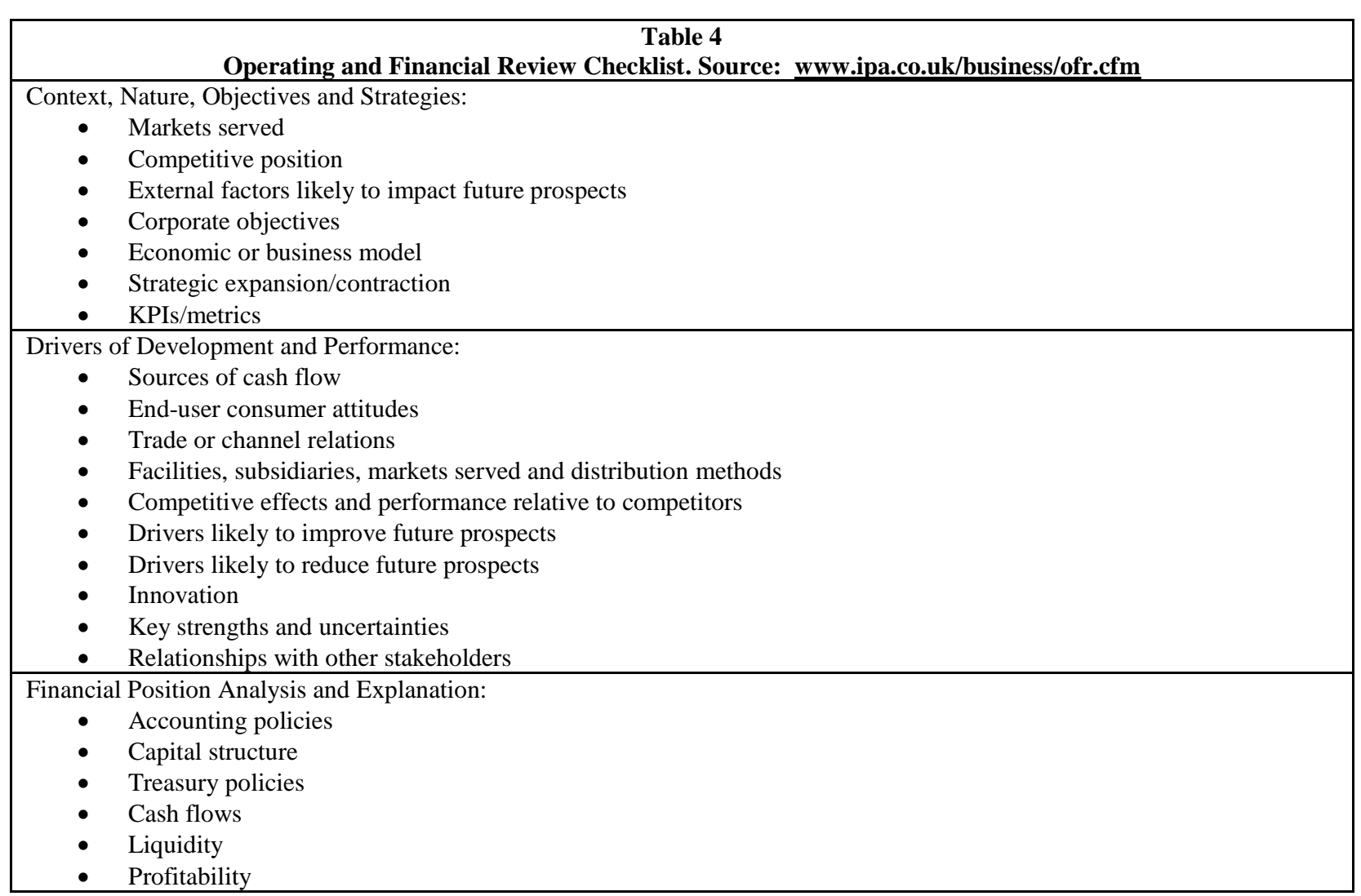

Therefore, firms that already have a comprehensive code of ethics will be ahead of the curve when these requirements become enforced in 2007.

\section{REFERENCES}

1. Deloitte Development LLC. 2005. Suggested Guidelines for Writing a Code of Ethics/Conduct. www.deloitte.com/us/corpgov.

2. Financial Reporting Council. 2006. ASB Issues Reporting Statement on the Operating and Financial Review. January 26, 2006. http://frc.org.uk/asb/press/pub1029.html.

3. Institute of Business Ethics. 2005. Business ethics - at the boardroom table but not the canteen table? February 18, 2005. www.ibe.org.uk.

4. IPA. Operating Financial Review. http://www.ipa.co.uk/business/ofr.cfm. 
International Business \& Economics Research Journal - September 2007

Volume 6, Number 9

\section{NOTES}

